\title{
DNA Repair Is More Important than Catalase for Salmonella Virulence in Mice
}

\author{
Nancy A. Buchmeier, ${ }^{\star}$ Stephen J. Libby,, Yisheng Xu, Peter C. Loewen, ${ }^{\S}$ Jacek Switala, ${ }^{\S}$ Donald G. Guiney, ${ }^{\ddagger}$ \\ and Ferric C. Fang \\ Departments of Medicine, Pathology, and Microbiology, University of Colorado Health Sciences Center, Denver, Colorado 80262; \\ * Department of Pathology, UCSD School of Medicine, La Jolla, California 92037; ${ }^{\ddagger}$ Department of Medicine, UCSD Medical Center, \\ San Diego, California 92103; and ${ }^{\S}$ Department of Microbiology, University of Manitoba, Winnipeg, Manitoba R3T 2N2, Canada
}

\begin{abstract}
Pathogenic microorganisms possess antioxidant defense mechanisms for protection from reactive oxygen metabolites such as hydrogen peroxide $\left(\mathrm{H}_{2} \mathrm{O}_{2}\right)$, which are generated during the respiratory burst of phagocytic cells. These defense mechanisms include enzymes such as catalase, which detoxify reactive oxygen species, and DNA repair systems which repair damage resulting from oxidative stress. To determine the relative importance of these two potentially protective defense mechanisms against oxidative stress encountered by Salmonella during infection of the host, a Salmonella typhimurium double mutant unable to produce either the HPI or HPII catalase was constructed, and compared with an isogenic recA mutant deficient in DNA repair. The recA mutant was hypersusceptible to $\mathrm{H}_{2} \mathrm{O}_{2}$ at low cell densities in vitro, while the catalase mutant was more susceptible to high $\mathrm{H}_{2} \mathrm{O}_{2}$ concentrations at high cell densities. The catalase mutant was found to be resistant to macrophages and retained full murine virulence, in contrast to the recA mutant which previously was shown to be macrophagesensitive and attenuated in mice. These observations suggest that Salmonella is subjected to low concentrations of $\mathrm{H}_{2} \mathrm{O}_{2}$ while at relatively low cell density during infection, conditions requiring an intact DNA repair system but not functional catalase activity. (J. Clin. Invest. 1995. 95:1047-1053.) Key words: oxidative stress • pathogenesis - macrophage • hydrogen peroxide $\cdot \operatorname{rec} A$
\end{abstract}

\section{Introduction}

Phagocytic cells are able to generate superoxide, hydrogen peroxide $\left(\mathrm{H}_{2} \mathrm{O}_{2}\right)$, and other reactive oxygen metabolites which are capable of damaging microbial DNA, proteins, and membranes (1). Microorganisms possess multiple defenses to oxidative stress which detoxify oxygen species, repair damage, and compete with phagocytes for oxygen $(1-3)$. The enzyme catalase plays a central role in these defenses, catalyzing the disproportionation of toxic $\mathrm{H}_{2} \mathrm{O}_{2}$ to water and oxygen.

A correlation between catalase activity and virulence has been noted for several pathogenic bacterial species, including

Address correspondence to Ferric C. Fang, 4200 E. Ninth Avenue, B168, Denver, CO 80262. Phone: 303-270-4857; FAX: 303-270-8681. 1994.

Received for publication 5 July 1994 and in revised form 13 October

J. Clin. Invest.

(c) The American Society for Clinical Investigation, Inc.

$0021-9738 / 95 / 03 / 1047 / 07 \quad \$ 2.00$

Volume 95, March 1995, 1047-1053
Staphylococcus aureus (4), Neisseria meningitidis (5), Legionella pneumophila (6), Nocardia asteroides (7), and Mycobacterium tuberculosis $(8,9)$. However, these studies were conducted using naturally occurring strains, raising the possibility that additional virulence determinants other than catalase might have differed between isolates. Two Listeria monocytogenes mutants lacking catalase activity were found to be fully virulent in mice (10), although these mutants interestingly were not susceptible to $\mathrm{H}_{2} \mathrm{O}_{2}$ in vitro. Catalase-deficient Shigella flexneri was found to be only modestly attenuated for virulence (11).

The ability to survive within phagocytic cells has been demonstrated to be an essential aspect of Salmonella virulence (12), suggesting that resistance to the phagocyte respiratory burst might be important to Salmonella. Moreover, Salmonella is one of the most common opportunistic pathogens in patients with chronic granulomatous disease, a genetic disorder characterized by a deficient phagocyte respiratory burst (13). Experimental data regarding the importance of oxidative killing mechanisms in Salmonella infection have been inconclusive (14-18). Attempts to define the role of catalase in Salmonella virulence have been hampered by the lack of defined mutants in isogenic strains (17).

Like Escherichia coli (19), Salmonella possesses two catalase proteins, hydroperoxidase I (HPI $)^{1}$ and hydroperoxidase II (HPII). HPI is encoded by the katG gene (20) and is regulated by oxy $\mathrm{R}$ in response to oxidative stress (21). HPII is encoded by kat $\mathrm{E}(22)$ is and regulated by an alternative sigma factor encoded by katF ( rpoS), in response to starvation $(23,24)$. Salmonella mutants lacking either of the catalase regulatory loci, oxy R $(12,21)$ or kat $\mathrm{F}(24)$, have been shown to be attenuated for virulence in mouse models, but these effects cannot be attributed to catalase alone since both oxy $\mathrm{R}$ and kat $\mathrm{F}$ regulate multiple genes.

A katE/katG $S$. typhimurium mutant unable to produce either the HPI or HPII catalases was constructed and evaluated with respect to susceptibility to $\mathrm{H}_{2} \mathrm{O}_{2}$ and phagocytic cells in vitro, and virulence in BALB/c mice. The double catalase mutant was compared with isogenic $S$. typhimurium mutants deficient in either catalase alone, with recA mutant $S$. typhimurium which is deficient in the ability to repair DNA damage, and with the virulent wild-type parent strain S. typhimurium $14028 \mathrm{~s}$.

\section{Methods}

Media. Luria-Bertani (LB) broth (tryptone, $10 \mathrm{mg} / \mathrm{ml}$; yeast extract, 5 $\mathrm{mg} / \mathrm{ml} ; \mathrm{NaCl}, 10 \mathrm{mg} / \mathrm{ml}$ ) at $37^{\circ} \mathrm{C}$ was used for all bacterial cultivation. Agar (1.5\%) was added to solid medium. Media were supplemented with $250 \mu \mathrm{g} / \mathrm{ml}$ penicillin or $15 \mu \mathrm{g} / \mathrm{ml}$ tetracycline (Sigma Chemical

1. Abbreviations used in this paper: HP, hydroperoxidase; LB, LuriaBertani; NBT, nitroblue tetrazolium. 
Table I. Bacterial Strains

\begin{tabular}{|c|c|c|}
\hline Strain & Relevant characteristics & Reference \\
\hline $14028 s$ & Wild-type & 12 \\
\hline CL1000 & $\operatorname{rec} \mathrm{A}$ & 15 \\
\hline MS7953 & phoP::Tn10 Tet $^{\mathrm{r}}$ & 12 \\
\hline SF1005 & katF::pRR10 $\Delta t r f \mathrm{~A} \mathrm{Pen}^{\mathrm{r}}$ & 24 \\
\hline MS4999 & kat $\mathrm{E}:: \operatorname{Tn} 10$ & 12 \\
\hline XF1000 & $k a t \mathrm{G}:: \mathrm{pRR} 10 \Delta \operatorname{trfA} \mathrm{Pen}^{\mathrm{r}}$ & This work \\
\hline XF1001 & $k a t \mathrm{E} / k a t \mathrm{G}$ & This work \\
\hline TH2423 & Contains $\mathrm{P} 22$ on a mini-F plasmid & 27 \\
\hline E. coli $\mathrm{S} 17-1$ & $\mathrm{Tra}^{+}$recA pro thi hsdR chr::RP4-2 & 28 \\
\hline $\mathrm{pRR} 10$ & RK2 mini-replicon & 29 \\
\hline
\end{tabular}

Co., St. Louis, MO) as indicated. Green plates (25) were used to identify cells not harboring bacteriophage P22 as a pseudo-lysogen. Macrophages were cultured in endotoxin-free RPMI plus $10 \%$ fetal calf serum (26).

Bacterial strains and plasmids. Strains used in this study are listed in Table I. All studies were performed using wild-type $S$. typhimurium ATCC 14028s or isogenic derivatives. The construction of catalasedeficient $S$. typhimurium MS4999s (katE), S. typhimurium XF1000 (kat $\mathrm{G})$, and $S$. typhimurium XF1001 (kat E/kat $\mathrm{G})$ is described in Results. S. typhimurium TH2423 contains bacteriophage P22 on a mini-F plasmid (27) and was used for preparation of transducing lysates from rough Salmonella strains. E. coli S17-1 (28) is a donor strain used to mobilize the pRR10-based suicide vector for the construction of $S$. typhimurium XF1000. pRR10 is a mobilizable RK2 mini-replicon encoding $\beta$-lactam resistance (29).

PCR. PCR was used to amplify an internal 796-bp sequence of kat $\mathrm{G}$ from $S$. typhimurium 14028s genomic DNA by a published method (30). The primers 5'-TGGTGGCCGAACAAGCTTCGCGTGG-3' and 5'-TGCTGGCCCAACTTAAGCCCTGCGC-3' were derived from the published $k a t \mathrm{G}$ sequence (20).

Catalase assay. Quantitative catalase assays were performed with an oxygraph (31), with activity expressed as units per milligram of dry weight. Catalase activity was visualized on $9.5 \%$ nondenaturing polyacrylamide gels (32).

Hydrogen peroxide susceptibility assay. The susceptibility of stationary phase bacterial cells to $\mathrm{H}_{2} \mathrm{O}_{2}$ was initially determined by adding $\mathrm{H}_{2} \mathrm{O}_{2}$ to bacteria in LB broth to a final concentration of $15 \mathrm{mM}$. Stationary phase bacteria were chosen for study since many critical antioxidant defenses are preferentially expressed during stationary phase $(23,33)$. Aliquots of bacteria were removed at timed intervals, diluted, and plated onto LB agar for quantitation of viable cells (24). Alternatively, 400 $\mu \mathrm{M}$ or $4 \mathrm{mM} \mathrm{H}_{2} \mathrm{O}_{2}$ was added to stationary phase bacteria diluted to either $5 \times 10^{5}$ or $10^{8}$ cells $/ \mathrm{ml}$ in M9 broth as indicated, before quantitation by plating at timed intervals.

Macrophage survival assay. The 24-h survival of Salmonella mutants in macrophages was assayed using proteose peptone-elicited macrophages as previously described (26). Short-term survival assays were performed in a similar manner but without the addition of gentamicin to the cultures. Production of a respiratory burst by macrophages was detected by the reduction of nitroblue tetrazolium (NBT) in a microplate assay (34). The production of $\mathrm{H}_{2} \mathrm{O}_{2}$ was measured using a microassay based on horseradish peroxidase-dependent oxidation of phenol red (34).

Mouse virulence assay. The virulence of the Salmonella catalase mutants was determined in 7-wk-old female BALB/c mice (Jackson Laboratories, Bar Harbor, ME) after intragastric or intraperitoneal adminstration (26).
Figure 1. Catalase gel of Salmonella catalase mutants. Gels were prepared by the method of Gregory and Fridovich (32). Cell extracts were examined from wildtype (lane 1), katE mutant (lane 2), kat $\mathrm{G}$ mutant (lane 3), and katE/kat $\mathrm{G}$ mutant (lane 4) S. typhimurium. The two bands corresponding to the HPI catalase (KatG) and the single band corresponding to the HPII catalase (KatE) are designated. The dark band corresponds to peroxidase activity, which is unaffected by the catalase mutations.

\section{Results}

Construction of catalase-deficient Salmonella mutants. A 796bp PCR-amplified internal kat $\mathrm{G}$ fragment (20) was cloned into a suicide vector based upon the RK2-derivative pRR10 (29) and conjugally transferred into $S$. typhimurium 14028s. Insertional inactivation of $k a t \mathrm{G}$ resulted from homologous recombination of the suicide vector into the bacterial chromosome. This kat $\mathrm{G}$ mutant strain was designated XF1000. The rough katE Tn10 mutant MS4999r was obtained (12) and the katE mutation was transduced into a smooth wild-type (14028s) background using TH2423 (27), resulting in strain MS4999s. The same P22 lysate was used to introduce the katE mutation into XF1000, resulting in the katE/katG mutant $S$. typhimurium strain XF1001.

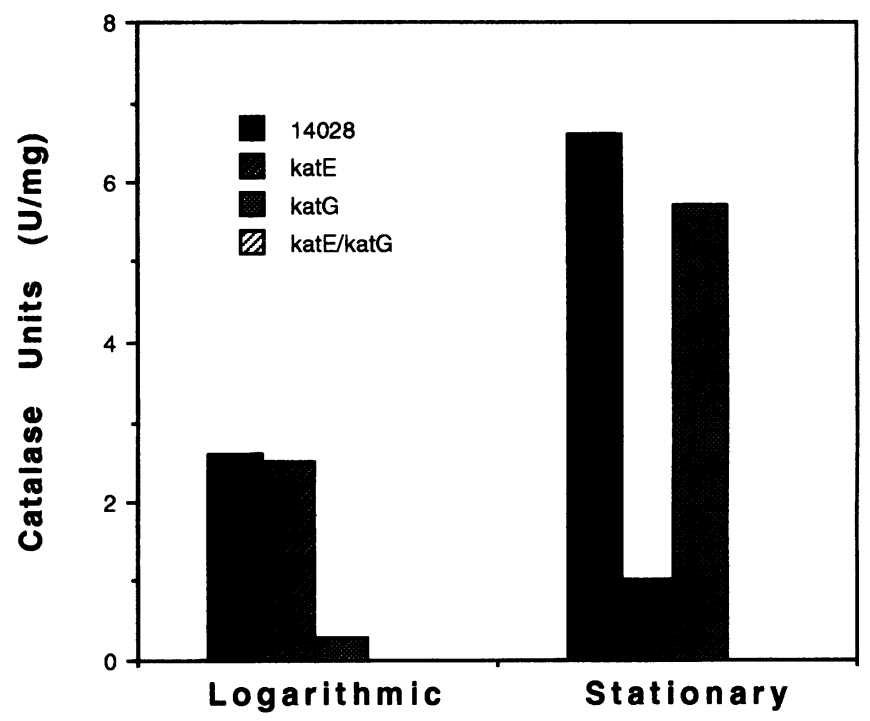

Figure 2. Catalase activity expressed by Salmonella catalase mutants. Catalase activity was assayed using an oxygraph (31). In wild-type $S$. typhimurium 14028s, the katE-encoded HPII accounts for 11 and $83 \%$ of the total catalase activity during logarithmic growth and stationary phase, respectively. The measured catalase activity from kat $\mathrm{E} / \mathrm{kat} \mathrm{G}$ mutant $S$. typhimurium during both logarithmic growth and stationary phase was $<0.01 \mathrm{U} / \mathrm{ml}$. 


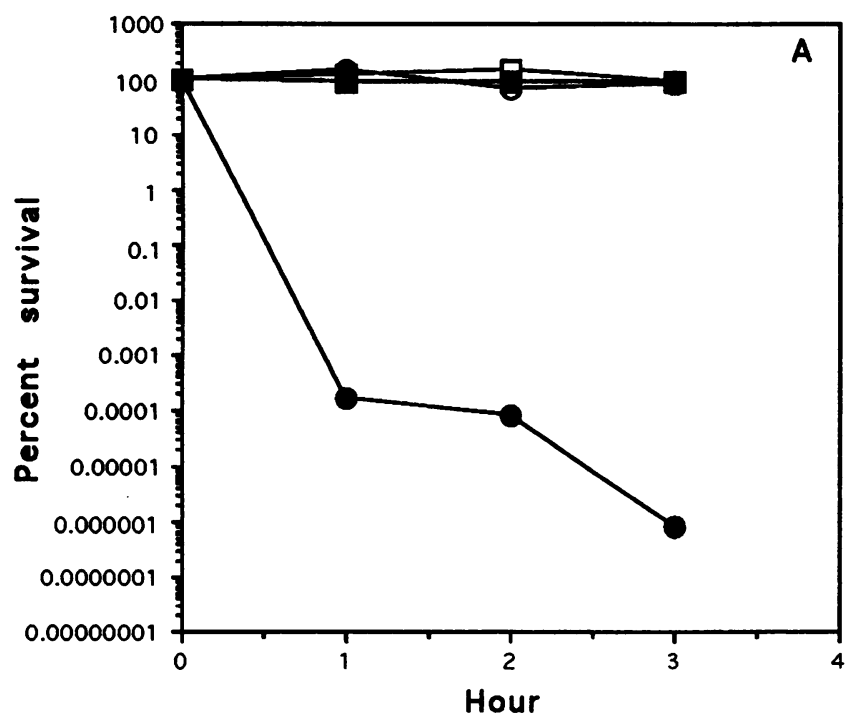

High density, $400 \mu M$ hydrogen peroxide

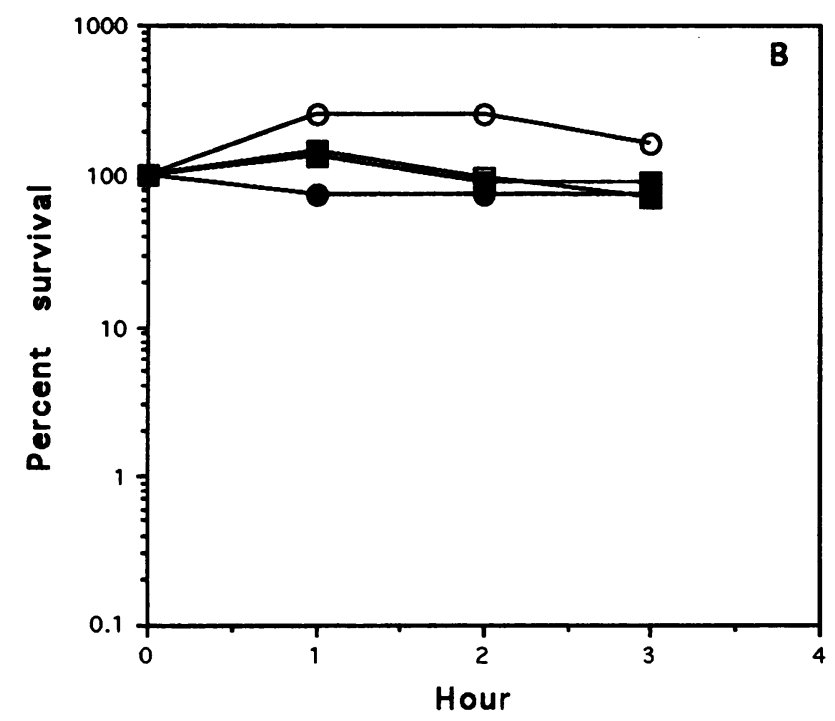

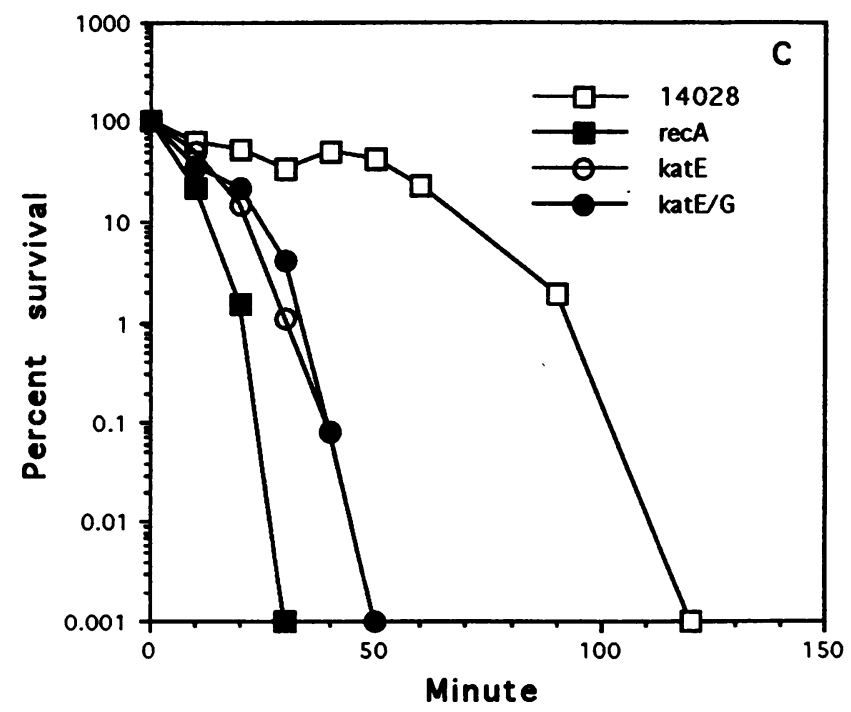

Low density, $400 \mu M$ hydrogen peroxide

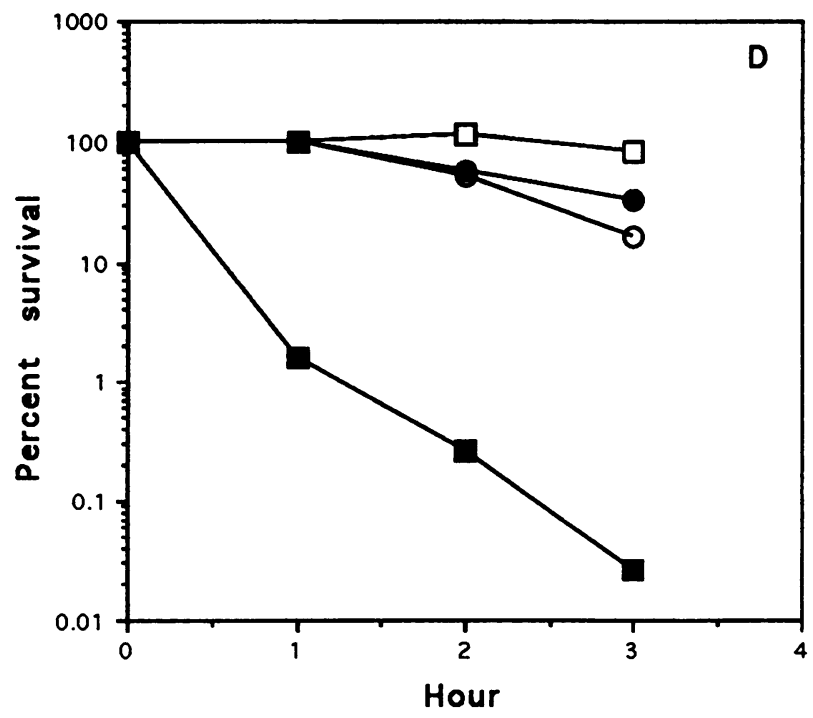

Figure 3. Sensitivity of Salmonella at high and low density to hydrogen peroxide. Stationary phase wild-type (open squares), recA mutant (closed squares), kat $\mathrm{E}$ mutant (open circles), and kat $\mathrm{E} /$ kat $\mathrm{G}$ mutant (closed circles) S. typhimurium were resuspended in $\mathrm{M} 9$ broth to either $10^{8} / \mathrm{ml}(A$ and $B$ ) or $5 \times 10^{5} / \mathrm{ml}(C$ and $D)$ and added to hydrogen peroxide to give a final concentration of $4 \mathrm{mM}(A$ and $C)$ or $400 \mu \mathrm{M}(B$ and $D)$. Samples were incubated at $37^{\circ} \mathrm{C}$ and aliquots were removed at timed intervals and plated for viable counts. Percent survival was calculated using the mean of duplicate samples at timed intervals compared to $0 \mathrm{~h}$. Each sensitivity assay was performed three times.

The catalase-deficient phenotypes of the mutant $S$. typhimurium strains were confirmed by analyzing bacterial lysates on catalase activity gels (32). As shown in Fig. 1, XF1000 expresses only the katE-encoded HPII catalase, MS4999s expresses only the katG-encoded HPI catalase which is visualized as a doublet (35), and XF1001 expresses neither catalase. Catalase activity expressed by the mutant strains as measured by oxygraph is shown in Fig. 2. The katE-encoded HPII catalase accounted for $11 \%$ of all catalase activity during logarithmic growth and $83 \%$ of total catalase activity during stationary phase.

Susceptibility of catalase-deficient Salmonella to hydrogen peroxide. Susceptibility of the catalase-deficient $S$. typhimurium strains to $\mathrm{H}_{2} \mathrm{O}_{2}$ was initially assessed using $1.0 \mathrm{ml}$ of an overnight culture $\left(\sim 10^{9}\right.$ bacteria/ml $)$ and $15 \mathrm{mM} \mathrm{H}_{2} \mathrm{O}_{2}$, a concentration well tolerated by wild-type $S$. typhimurium (24). Both the kat $\mathrm{E}$ and kat $\mathrm{G}$ single mutants were resistant to $15 \mathrm{mM}$ $\mathrm{H}_{2} \mathrm{O}_{2}$, but the double katE/katG mutant XF1001 was highly susceptible to $15 \mathrm{mM} \mathrm{H}_{2} \mathrm{O}_{2}$ with greater than 3 logs killing in $30 \mathrm{~min}$ and no viable cells detected by $60 \mathrm{~min}$.

Although the katE/kat $\mathrm{G}$ mutant was extremely sensitive to $\mathrm{H}_{2} \mathrm{O}_{2}$ as originally tested at a density of $10^{9}$ cells $/ \mathrm{ml}$, the protective effect of microbial catalase is known to be cell densitydependent (36). Therefore, $\mathrm{H}_{2} \mathrm{O}_{2}$ assays were repeated using 

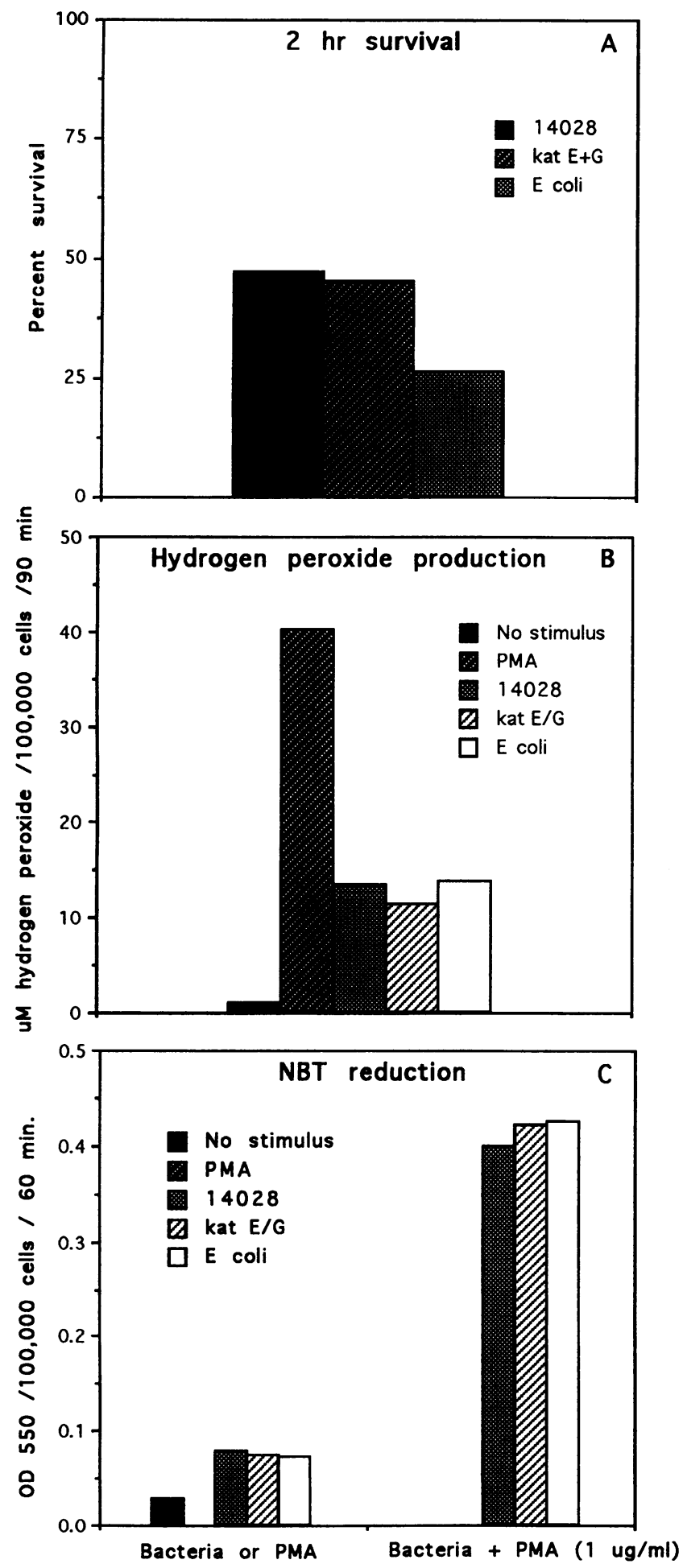

Figure 4. Survival and stimulation of oxidative burst by Salmonella in peritoneal exudate macrophages. $(A)$ Macrophages were infected with 20 bacteria/cell for $15 \mathrm{~min}$, washed four times and fresh medium containing no antibiotics was added. Triplicate wells were lysed and plated at 0 and $2 \mathrm{~h}(26)$. Percent survival is $2 \mathrm{~h}$ viable count $/ 0 \mathrm{~h}$ viable count. (B) $10^{5}$ macrophages were infected with $20 \mathrm{bacteria} /$ cell or stimulated with $1 \mu \mathrm{g} / \mathrm{ml}$ PMA and incubated for 90 min in media containing phenol red and horseradish peroxidase as described for the microassay (34). Hydrogen peroxide levels were determined at $\mathrm{OD}_{650}$ and compared with a standard curve. $(C) 10^{5}$ macrophages were infected with 20 bacteria/ cell or stimulated with $1 \mu \mathrm{g} / \mathrm{ml}$ PMA in media containing $1 \mathrm{mg} / \mathrm{ml}$ bacterial densities of $10^{8}$ cells $/ \mathrm{ml}$ and $5 \times 10^{5}$ cells $/ \mathrm{ml}$, which may be more similar to bacterial densities during infection studies. In these experiments, the catalase mutants were compared with the isogenic recA mutant $S$. typhimurium CL1000, which is sensitive to DNA-damaging compounds and attenuated for virulence in both macrophages and mice (15). At low cell densities, the recA mutant was the most sensitive strain tested to $\mathrm{H}_{2} \mathrm{O}_{2}$. Low concentration $(400 \mu \mathrm{M}) \mathrm{H}_{2} \mathrm{O}_{2}$ killed only the recA strain in a significant manner, while the catalase mutants of $S$. typhimurium were virtually resistant to $400 \mu \mathrm{M} \mathrm{H}_{2} \mathrm{O}_{2}$ (Fig. 3 ). When the concentration of $\mathrm{H}_{2} \mathrm{O}_{2}$ was increased 10 -fold to $4 \mathrm{mM}$, the recA mutant was inactivated most rapidly, followed by the catalase mutants and then wild-type organisms. In contrast, at high cell density the double catalase mutant of $S$. typhimurium displayed the greatest susceptibility to high concentration ( $4 \mathrm{mM}$ ) $\mathrm{H}_{2} \mathrm{O}_{2}$.

Susceptibility of catalase-deficient Salmonella to macrophages. Survival of the double katE/katG mutant S. typhimurium (XF1001) was compared with that of wild-type 14028s in peptone-elicited macrophages. There was no difference in survival in a 24-h assay (data not shown). Bacterial killing during the first $2 \mathrm{~h}$ of infection when the peak oxidative burst is produced was then examined. Peritoneal exudate macrophages were infected with 20 bacteria/cell for $15 \mathrm{~min}$, washed extensively before fresh media without antibiotics were added, and incubated for another $2 \mathrm{~h}$. There was no difference in the susceptibility of the double kat $\mathrm{E} / \mathrm{kat} \mathrm{G}$ mutant to killing by macrophages compared to wild-type $S$. typhimurium (Fig. 4 A).

The respiratory burst of the peritoneal exudate macrophages was measured in parallel to verify that the macrophages were producing oxidative products, to determine whether the bacterial inoculum used was sufficient to trigger a burst, and to determine whether infection with $S$. typhimurium inhibited the respiratory burst when triggered by a second stimulus. After stimulation with $1 \mu \mathrm{g} / \mathrm{ml}$ PMA, the peritoneal macrophages produced $\mathrm{H}_{2} \mathrm{O}_{2}$ (Fig. $4 \mathrm{~B}$ ) and reduced NBT (Fig. $4 \mathrm{C}$ ). Infection with bacteria stimulated less oxidative burst than the PMA, however both $S$. typhimurium 14028 s and the kat $\mathrm{E} /$ kat $\mathrm{G}$ mutant stimulated the production of similar amounts of oxidative products as E. coli (Fig. $4 C$ ), which was used as a control organism carrying LPS but lacking the ability to survive in macrophages. The detectable concentration of $\mathrm{H}_{2} \mathrm{O}_{2}$ in the cultures was $\sim 10$ $\mu \mathrm{M}$ after stimulation with bacteria. Infecting macrophages with bacteria at the same time that PMA was added did not reduce the oxidative burst, but enhanced it twofold over PMA alone as detected by NBT reduction (Fig. $4 C$ ).

Virulence of catalase-deficient Salmonella in BALB/c mice. Virulence of the catalase mutants was assayed in BALB/c mice. The double catalase Salmonella mutant XF1001 was not attenuated as measured by either lethal dose or time until death. All mice given $10^{3} \mathrm{CFU}$ of the kat $\mathrm{E} / \mathrm{kat} \mathrm{G}$ mutant intraperitoneally were dead by day 5 , which was identical to mice infected with wild-type 14028s (Fig. 5 A). Mice infected with the kat $\mathrm{F}$ mutant SF1005 displayed no signs of infection, providing evidence of

NBT and incubated for $60 \mathrm{~min}$. Reduction of NBT was measured as $\mathrm{OD}$ at $550 \mathrm{~nm}$ (34). For double stimulation, cells were infected with 20 bacteria/cell using media containing $1 \mu \mathrm{g} / \mathrm{ml}$ PMA and incubated for $60 \mathrm{~min}$. Each survival or stimulation assay was performed three times. 

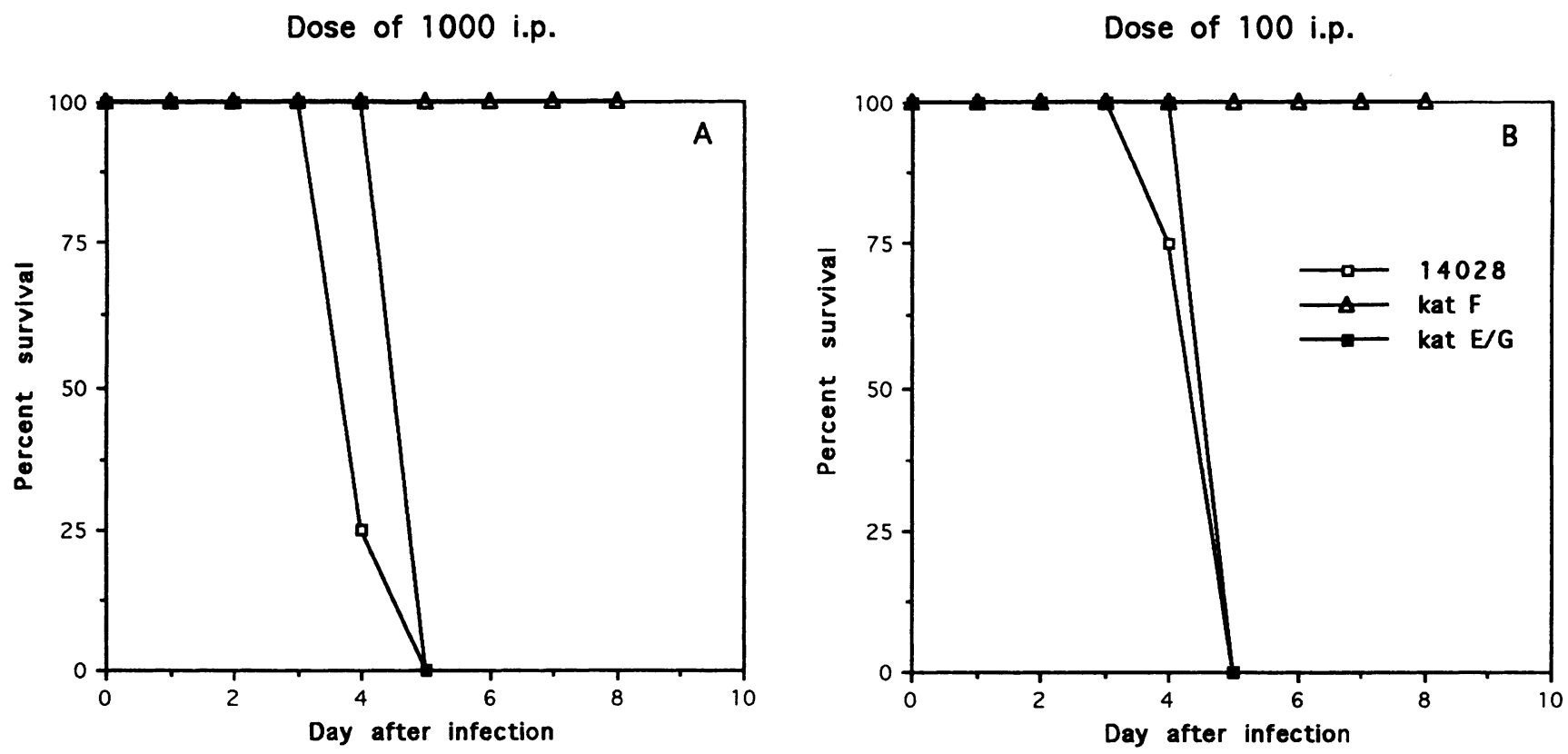

Figure 5. Virulence of catalase mutants in mice. Groups of female BALB/c mice were infected intraperitoneally with either $10^{3} \mathrm{CFU}(A)$ or $10^{2}$ $\mathrm{CFU}(B)$ of bacteria. No significant difference in the virulence of wild-type (open squares) and kat $\mathrm{E} / \mathrm{kat} \mathrm{G}$ mutant (closed squares) S. typhimurium was seen. $k a t \mathrm{~F}$ mutant $S$. typhimurium (open triangles) was included as an attenuated control strain (24). Each intraperitoneal virulence determination was performed twice, using four mice per group.

its attenuation as previously described (24). The recA mutant CL1000 recently has been demonstrated to have attenuated virulence in mice (15), hence virulence testing with this strain was not repeated. Reducing the infecting dose of the kat $\mathrm{E} / \mathrm{kat} \mathrm{G}$ mutant to $10^{2}$ bacteria intraperitoneally still failed to reveal any evidence of attenuation (Fig. $5 \mathrm{~B}$ ). Infection by the oral route similarly showed no reduction in virulence of the $k a t \mathrm{E} / \mathrm{kat} \mathrm{G}$ mutant (data not shown).

\section{Discussion}

Hydrogen peroxide $\left(\mathrm{H}_{2} \mathrm{O}_{2}\right)$ is an important component of the respiratory burst. Although $\mathrm{H}_{2} \mathrm{O}_{2}$ itself is considered to be only weakly microbicidal (37), it is an important component of the phagocyte respiratory burst because of its ability to diffuse rapidly across membranes. Once within the bacterial cell, $\mathrm{H}_{2} \mathrm{O}_{2}$ may react with iron or copper ions to generate highly cytotoxic hydroxyl radicals $(\mathrm{OH} \cdot)$ via the Fenton reaction (2). The enzyme catalase catalyzes the disproportionation of $\mathrm{H}_{2} \mathrm{O}_{2}$ into water and oxygen. This reaction might be anticipated to be particularly important in the virulence of intracellular pathogens such as Salmonella, which reside within the phagosomes of host phagocytic cells (38).

However, this study demonstrates that catalase does not play a necessary role in S. typhimurium virulence in mice. Mutations in both the katE- and kat $\mathrm{G}$-encoded catalases of S. typhimurium were constructed to eliminate ambiguities arising from the use of nonisogenic strains and to avoid multigenic effects resulting from disruption of pleiotropic regulatory genes. kat $\mathrm{E} / \mathrm{kat} \mathrm{G} \mathrm{mu}-$ tant $S$. typhimurium lacks detectable catalase activity and demonstrates increased susceptibility to $\mathrm{H}_{2} \mathrm{O}_{2}$ in vitro. Nonetheless, this mutant shows no significant attenuation for virulence by either oral or intraperitoneal infection in $\mathrm{BALB} / \mathrm{c}$ mice. This is in contrast to kat $\mathrm{F}$ (rpoS) mutant $S$. typhimurium, which is attenuated for virulence; this finding confirms that the avirulence of the kat $\mathrm{F}$ mutant results from disrupted expression of $k a t \mathrm{~F}$-regulated genes other than kat $\mathrm{E}$, such as the $s p v$ plasmid virulence genes (24). Moreover, although kat $\mathrm{E} /$ kat $\mathrm{G}$ mutants are hypersusceptible to $\mathrm{H}_{2} \mathrm{O}_{2}$ killing in vitro, single kat $\mathrm{E}$ or kat $\mathrm{G}$ mutants did not demonstrate increased $\mathrm{H}_{2} \mathrm{O}_{2}$ susceptibility in a conventional $\mathrm{H}_{2} \mathrm{O}_{2}$-killing assay. Since kat $\mathrm{F}$ mutant $S$. typhimurium is $\mathrm{H}_{2} \mathrm{O}_{2}$ sensitive despite intact kat $\mathrm{G}$ expression (24), this implicates katF-regulated functions other than catalase in the mechanism of Salmonella resistance to $\mathrm{H}_{2} \mathrm{O}_{2}$, perhaps involving the dps (33) or xthA loci (23).

The Salmonella catalase proteins were also found to be unnecessary for either long-term $(24 \mathrm{~h})$ or short-term $(2 \mathrm{~h})$ survival in macrophages in vitro. This finding complements earlier observations that induction of catalase expression does not appear to enhance survival of $E$. coli in polymorphonuclear neutrophils (39). Other investigators have recently shown that mutations in $\operatorname{oxy} \mathrm{R}$ or the oxy $\mathrm{R}$-regulated kat $\mathrm{G}$ gene encoding the HPI catalase also fail to significantly alter $S$. typhimurium LT2 survival after exposure to neutrophils (40). The peritoneal exudate macrophages used in this study were demonstrated to be capable of producing a respiratory burst in response to phagocytosis of bacteria or PMA stimulation. Only low levels of $\mathrm{H}_{2} \mathrm{O}_{2}(10 \mu \mathrm{M})$ were detected in the tissue culture medium of stimulated macrophages, but this undoubtedly underestimates $\mathrm{H}_{2} \mathrm{O}_{2}$ production since rapid catalatic or peroxidatic breakdown of $\mathrm{H}_{2} \mathrm{O}_{2}$ occurs under these assay conditions (41). No inhibition of the respiratory burst by Salmonella was observed. Macrophages infected with Salmonella produced similar levels of reactive oxygen products compared to $E$. coli-infected macrophages. Simultaneously stimulating with PMA and infecting with Salmonella produced an amplified oxidative burst. Simi- 
larly, other investigators using Salmonella typhi or S. typhimurium LT2 have shown that Salmonella triggers the production of hydrogen peroxide in murine resident peritoneal macrophages (14). Francis and Gallagher (42) have recently provided evidence that intracellular Salmonella comes into contact with $\mathrm{H}_{2} \mathrm{O}_{2}$. Using Salmonella containing an $\mathrm{H}_{2} \mathrm{O}_{2}$-responsive $\mathrm{Mu} d$ lux gene fusion, they demonstrated maximal expression of the reporter gene 80-90 min after Salmonella infection of J774 macrophages (42).

One of the most striking findings of this study is the variation in relative susceptibility of catalase-deficient ( $k a t \mathrm{E} / \mathrm{kat} \mathrm{G}$ ) and DNA repair-deficient (recA) Salmonella depending upon the in vitro conditions of $\mathrm{H}_{2} \mathrm{O}_{2}$ concentration and cell density. Catalase-deficient mutants are more susceptible to high $\mathrm{H}_{2} \mathrm{O}_{2}$ concentrations at high cell density than the repair-deficient mutant, while the repair-deficient mutant is more susceptible to $\mathrm{H}_{2} \mathrm{O}_{2}$ at low cell density. These observations help to extend and reconcile prior conflicting reports regarding the relative importance of catalase and DNA repair mechanisms in bacterial susceptibility to $\mathrm{H}_{2} \mathrm{O}_{2}(22,43,44)$. Imlay and Linn (44) have previously suggested that DNA damage is the predominant lethal action caused by low concentrations of $\mathrm{H}_{2} \mathrm{O}_{2}(\leq 1 \mathrm{mM})$. Therefore, recA mutant $S$. typhimurium is highly susceptible to $\mathrm{H}_{2} \mathrm{O}_{2}$ killing occurring at low peroxide concentrations and low cell density. At higher $\mathrm{H}_{2} \mathrm{O}_{2}$ concentrations, cell death results from a mixture of DNA damage and injury to other undefined cell targets (1). Hence, recA and DNA repair play only a partial role in the cellular defenses against this mode of damage (44). At high cell densities in vitro, catalase-containing bacteria are able to lower ambient $\mathrm{H}_{2} \mathrm{O}_{2}$ concentrations by mass effect. However, the protection afforded by catalase decreases proportionally at low cell densities (36), because the rate of $\mathrm{H}_{2} \mathrm{O}_{2}$ diffusion into single cells appears to exceed the rate of degradation by cellular catalase. As predicted by this model, the protective effect of high cell density is abrogated in mutant $S$. typhimurium unable to produce catalase (Fig. 3 ).

The identification of mutants with differential susceptibility to killing by $\mathrm{H}_{2} \mathrm{O}_{2}$ under various in vitro conditions provides biological sensors to determine the oxidative stress experienced by Salmonella within host phagocytes. While katE/katG mutant $S$. typhimurium retains full virulence in vivo and the ability to survive in macrophages in vitro, recA mutant $S$. typhimurium demonstrates attenuated virulence in mice and reduced survival in macrophages (15), which appears to be dependent upon the respiratory burst capability of the phagocytic cells. The in vitro conditions of low $\mathrm{H}_{2} \mathrm{O}_{2}$ concentration $(400 \mu \mathrm{M})$ and low cell density $\left(5 \times 10^{5}\right.$ cells $\left./ \mathrm{ml}\right)$, to which the recA strain is most susceptible of the mutants tested, appear to best reflect the conditions encountered by Salmonella during in vivo infection (15). Under these conditions, the ability to repair DNA damage is more important to microbial survival than the ability to directly inactive $\mathrm{H}_{2} \mathrm{O}_{2}$.

\section{Acknowledgments}

The authors are grateful to Fred Heffron for the generous gifts of strains MS4999r and TH2423.

This work was supported in part by Public Health Service grants AI-29566 (N. Buchmeier), AI-32178 (D. Guiney), AM-35108 (D. Guiney), and AI-32463 (F. Fang), and USDA grant 9401954 (F. Fang).

\section{References}

1. Hassett, D. J., and M. S. Cohen. 1989. Bacterial adaptation to oxidative stress: implications for pathogenesis and interaction with phagocytic cells. FASEB (Fed. Am. Soc. Exp. Biol.) J. 3:2574-2582.

2. Storz, G., L. A. Tartaglia, S. B. Farr, and B. N. Ames. 1990. Bacterial defenses against oxidative stress. Trends Genet. 6:363-368.

3. Farr, S. B., and T. Kogoma. 1991. Oxidative stress responses in Escherichia coli and Salmonella typhimurium. Microbiol. Rev. 55:561-585.

4. Mandell, G. L. 1975. Catalase, superoxide dismutase, and virulence of Staphylococcus aureus. In vitro and in vivo studies with emphasis on staphylococcal-leukocyte interaction. J. Clin. Invest. 55:561-566

5. Hassan, H. M., A. Bhatti, and L. A. White. 1984. Superoxide dismutase, catalase and peroxidase in four strains of Neisseria meningitidis of different virulence. FEMS (Fed. Eur. Microbiol. Soc.) Microbiol. Lett. 25:71-74.

6. Jepras, R. I., and R. B. Fitzgeorge. 1986. The effect of oxygen-dependent antimicrobial systems on strains of Legionella pneumophila of different virulence. J. Hyg. 97:61-69.

7. Beamen, L., and B. L. Beaman. 1984. The role of oxygen and its derivatives in microbial pathogenesis and host defense. Annu. Rev. Microbiol. 38:27-48.

8. Jackett, P. S., V. R. Aber, and D. B. Lowrie. 1978. Virulence and resistance to superoxide, low $\mathrm{pH}$ and hydrogen peroxide among strains of Mycobacterium tuberculosis. J. Gen. Microbiol. 104:37-45.

9. Zhang, Y., T. Garbe, and D. Young. 1993. Transformation with katG restores isoniazid-sensitivity in Mycobacterium tuberculosis isolates resistant to a range of drug concentrations. Mol. Microbiol. 8:521-524.

10. Leblond-Francillard, M., J. Gaillard, and P. Berche. 1989. Loss of catalase activity in Tn1545-induced mutants does not reduce growth of Listeria monocytogenes in vivo. Infect. Immun. 57:2569-2573.

11. Franzon, V. L., J. Arondel, and P. J. Sansonetti. 1990. Contribution of superoxide dismutase and catalase activities to Shigella flexneri pathogenesis. Infect. Immun. 58:529-535.

12. Fields, P. I., R. V. Swanson, C. G. Haidaris, and F. Heffron. 1986. Mutants of Salmonella typhimurium that cannot survive within the macrophage are avirulent. Proc. Natl. Acad. Sci. USA. 83:5189-5193.

13. Mouy, R., A. Fischer, E. Vilmer, R. Seger, and C. Griscelli. 1989. Incidence, severity, and prevention of infections in chronic granulomatous disease. J. Pediatr. 114:555-560.

14. Ishibashi, Y., and T. Arai. 1989. Susceptibility of Salmonella typhimurium and Salmonella typhi to oxygen metabolites. FEMS (Fed. Eur. Microbiol. Soc.) Microbiol. Immunol. 1:279-284.

15. Buchmeier, N., C. J. Lipps, M. H. Y. So, and F. Heffron. 1993. Recombination-deficient mutants of Salmonella typhimurium are avirulent and sensitive to the oxidative burst of macrophages. Mol. Microbiol. 7:933-936.

16. Edwards, C. K. I., S. M. Ghiasuddin, L. M. Yunger, R. M. Lorence, S. Arkins, R. Dantzer, and K. W. Kelley. 1992. In vivo administration of recombinant growth hormone or gamma interferon activates macrophages: enhanced resistance to experimental Salmonella typhimurium infection is correlated with generation of reactive oxygen intermediates. Infect. Immun. 60:2514-2521.

17. Khurana, S., N. K. Ganguly, D. Panigrahi, M. Khullar, and B. N. Walia. 1991. The correlation of biochemical virulence factors and enterotoxin production with LD50 of Salmonella typhimurium in mice. Microbiologica (Pavia). 14:113117.

18. Kossack, R. E., R. L. Guerrant, P. Densen, J. Schadelin, and G. L. Mandell. 1981. Diminished neutrophil oxidative metabolism after phagocytosis of virulent Salmonella typhi. Infect. Immun. 31:674-678.

19. Loewen, P. C., J. Switala, and B. L. Triggs-Raine. 1985. Catalases HPI and HPII in Escherichia coli are induced independently. Arch. Biochem. Biophys. 243:144-149.

20. Loewen, P. C., and G. V. Stauffer. 1990. Nucleotide sequence of katG of Salmonella typhimurium LT2 and characterization of its product, hydroperoxidase I. Mol. Gen. Genet. 224:147-151.

21. Christman, M. F., R. W. Morgan, F. S. Jacobson, and B. N. Ames. 1985. Positive control of a regulon for defenses against oxidative stress and some heatshock proteins in Salmonella typhimurium. Cell. 41:753-762.

22. Loewen, P. C. 1984. Isolation of catalase-deficient Escherichia coli mutants and genetic mapping of kat $\mathrm{E}$, a locus that affects catalase activity. J. Bacteriol. 157:622-626.

23. Sak, B. D., A. Eisenstark, and D. Touati. 1989. Exonuclease III and the catalase hydroperioxidase II in Escherichia coli are both regulated by the katF gene product. Proc. Natl. Acad. Sci. USA. 86:3271-3275.

24. Fang, F. C., S. J. Libby, N. A. Buchmeier, P. C. Loewen, J. Switala, J. Harwood, and D. G. Guiney. 1992. The alternative $\sigma$ factor KatF (RpoS) regulates Salmonella virulence. Proc. Natl. Acad. Sci. USA. 89:11978-11982.

25. Smith, H. O., and M. Levine. 1967. A phage P22 gene controlling integration of prophage. Virology. 31:207-216.

26. Buchmeier, N. A., and F. Heffron. 1989. Intracellular survival of wildtype Salmonella typhimurium and macrophage-sensitive mutants in diverse populations of macrophages. Infect. Immun. 57:1-7.

27. Elliott, T. 1989. Cloning, genetic characterization, and nucleotide sequence 
of the hemA-prf A operon of Salmonella typhimurium. J. Bacteriol. 171:39483960.

28. Simon, R., M. O’Connell, M. Labes, and A. Pühler. 1986. Plasmid vectors for the genetic analysis and manipulation of Rhizobia and other Gram-negative bacteria. Methods Enzymol. 118:640-659.

29. Roberts, R. C., R. Burioni, and D. R. Helinski. 1990. Genetic characterization of the stabilizing functions of a region of broad-host-range plasmid RK2. $J$. Bacteriol. 172:6204-6216.

30. Sambrook, J., E. F. Fritsch, and T. Maniatis. 1989. Molecular Cloning: A Laboratory Manual. Cold Spring Harbor Laboratory Press, Cold Spring Harbor, NY.

31. Loewen, P. C., and B. L. Triggs. 1984. Genetic mapping of katF, a locus that with katE affects the synthesis of a second catalase species in Escherichia coli. J. Bacteriol. 160:668-675.

32. Gregory, E. M., and I. Fridovich. 1974. Visualization of catalase on acrylamide gels. Anal. Biochem. 58:57-62.

33. Almirón, M., A. Link, D. Furlong, and R. Kolter. 1992. A novel DNA binding protein with regulatory and protective roles in starved Escherichia coli. Genes. \& Dev. 6:2646-2654.

34. Pick, E. 1986. Microassays for superoxide and hydrogen peroxide production and nitroblue tetrazolium reduction using an enzyme immunoassay microplate reader. Methods Enzymol. 132:407-421.

35. Loewen, P. C., B. L. Triggs, C. S. George, and B. E. Hrabarchuk. 1985. Genetic mapping of katG, a locus that affects synthesis of the bifunctional catalaseperoxidase hydroperoxidase I in Escherichia coli. J. Bacteriol. 162:661-667.
36. Ma, M., and J. W. Eaton. 1992. Multicellular oxidant defense in unicellular organisms. Proc. Natl. Acad. Sci. USA. 89:7924-7928.

37. Babior, B. 1984. The respiratory burst of phagocytes. J. Clin. Invest. 73:599-601.

38. Finlay, B. B., and S. Falkow. 1989. Salmonella as an intracellular parasite. Mol. Microbiol. 3:1833-1841.

39. Schwartz, C. E., J. Krall, L. Norton, K. McKay, D. Kay, and R. E. Lynch. 1983. Catalase and superoxide dismutase in Escherichia coli. J. Biol. Chem. 258:6277-6281.

40. Papp-Szabò, E., M. Firtel, and P. D. Josephy. 1994. Comparison of the sensitivities of Salmonella typhimurium oxy $\mathrm{R}$ and kat $\mathrm{G}$ mutants to killing by human neutrophils. Infect. Immun. 62:2662-2668.

41. Winterbourn, C. C. 1990 . Neutrophil oxidants: production and reactions. In Oxygen Radicals: Systemic Events and Disease Processes. D. K. Das and W. B. Essman, editor. Karger, Basel. 31-70.

42. Francis, K. P., and M. P. Gallagher. 1993. Light emission from a Mudlux transcriptional fusion in Salmonella typhimurium is stimulated by hydrogen peroxide and by interaction with the mouse macrophage cell line J774.2. Infect. Immun. 61:640-649.

43. Carlsson, J., and V. S. Carpenter. 1980. The recA+ gene product is more important than catalase and superoxide dismutase in protecting Escherichia coli against hydrogen peroxide toxicity. J. Bacteriol. 142:319-321.

44. Imlay, J. A., and S. Linn. 1986. Bimodal pattern of killing of DNA-repairdefective or anoxically grown Escherichia coli by hydrogen peroxide. J. Bacteriol. 166:519-527. 